\title{
Análise Morfométrica e Feições Erosivas na Bacia Hidrográfica do Rio Taturi (PR)
}

\author{
Morphometric Analysis and Erosive Features in the Taturi River Basin (PR)
}

\section{Análisis Morfométrico y Características Erosivas en la Cuenca del Rio Taturi (PR)}

Higor Lourenzoni Bonzanini ${ }^{1}$

https://orcid.org/0000-0003-0135-3361

Cenira Maria Lupinacci ${ }^{2}$

https://orcid.org/0000-0002-4732-1421

Rafael Martins Sanches ${ }^{3}$

https://orcid.org/0000-0003-0941-0455

RESUMO: Este trabalho teve como objetivo avaliar as feições do relevo da bacia do Rio Taturi (PR), buscando identificar a inter-relação entre as litologias, as feições lineares vinculadas a fraturas e falhas, as feições erosivas e os tipos de forma de relevo. Para isso, foi realizado o mapeamento geomorfológico da área e o levantamento de dados morfoestruturais, por meio da elaboração das cartas de densidade de drenagem, profundidade de dissecação, clinográfica e lineamentos. A análise dessas cartas possibilitou identificar diferentes setores, determinados em sua grande maioria pela variação litológica e pelos lineamentos. Desta maneira, a bacia hidrográfica do Rio Taturi, apesar de sua morfologia de baixo declive, possui características morfológicas e, portanto, processuais, variadas, as quais estão vinculadas à litologia e aos lineamentos. Assim, os setores de domínio de litologias arenosas apresentam morfologias que indicam maior intensidade dos processos erosivos, 0 que deve ser considerado quando do uso e ocupação da terra.

PALAVRAS-CHAVE: Litologia. Feições geomorfológicas. Falhamentos.

ABSTRACT: This work aimed to evaluate the relief features of the Taturi River watershed Paraná state, Brazil, seeking to identify the interrelationship between the lithologies, the linear features linked

\footnotetext{
${ }^{1}$ Graduando em Geografia da Universidade Estadual Paulista “Júlio de Mesquita Filho", Campus Rio Claro. Email: higorbonza@gmail.com.

2 Doutora em Geociências e Meio Ambiente pela Universidade Estadual Paulista "Júlio de Mesquita Filho", Campus Rio Claro. Professora doutora da Universidade Estadual Paulista "Júlio de Mesquita Filho", Campus Rio Claro. E-mail: cenira.lupinacci@unesp.br.

${ }^{3}$ Doutorando em Geografia pela Universidade Estadual Paulista “Júlio de Mesquita Filho”, Campus Rio Claro. Email: rafaelmasanches@yahoo.com.br.
} 
to fractures and faults, erosive features and types of landforms. For that, the geomorphological mapping of the area and the survey of morphostructural data were cattied out, through the elaboration of the drainage density, dissection depth, slope and lineation maps. The analysis of these maps made it possible to identify different sectors, mostly determined by the lithological variation and by the lineaments. In this way, the hydrographic basin of the Taturi River, despite its low slope morphology, has morphological and, therefore, varied procedural characteristics, wich are linked to lithology and lineaments. Thus, the domain sectors of sandy lithologies present morphologies that indicate greater intensity of erosive processes, which must be considered when using and occupying the land.

KEYWORDS: Lithology. Geomorphological features. Failures.

RESUMEN: Este trabajo tuvo como objetivo evaluar los rasgos de relieve de la cuenca del Río Taturi estado de Paraná, Brasil, buscando identificar la interrelación entre las litologías, los rasgos lineales vinculados a fracturas y fallas, los rasgos erosivos y los tipos de accidentes geográficos. Para ello, se realizó el mapeo geomorfológico del área y el levantamiento de datos morfoestructurales, mediante la elaboración de los diagramas de densidad de drenaje, profundidad de disección, pendiente ylineamiento. El análisis de estas letras permitió identificar diferentes sectores, en su mayoría determinados por la variación litológica y por los lineamientos. De esta forma, la cuenca hidrográfica del Río Taturi, a pesar de su morfología de baja pendiente, presenta características morfológicas y, por tanto, procedimentales variadas que están ligadas a la litología y los lineamentos. Así, los sectores de dominio de las litologías arenosas presentan morfologías que indican mayor intensidad de procesos erosivos, los cuales deben ser considerados a la hora de utilizar y ocupar el terreno.

PALABRAS-CLAVE: Litología. Características geomorfológicas. Fallas geológicas.

\section{INTRODUÇÃO}

A dinâmica geomorfológica em regiões tectonicamente estáveis e de topografia aplainada, teoricamente propícias às ações intempéricas e à pedogênese em ambientes quentes e úmidos, necessita ser conhecida, visto que o uso da terra, aproveitando-se dos baixos declives, muitas vezes é realizado de forma intensa, nem sempre propiciando condições de equilíbrio entre o desenvolvimento dos solos e as ações denudacionais.

O setor oeste do Estado do Paraná enquadra-se nessas condições de relevo suavizado e de intenso uso da terra. O caráter plano do relevo tem sido estudado há bastante tempo, sendo tal morfologia atribuída a processos de aplainamento que deram origem a diversos pediplanos. Assim, Bigarella e Mazuchowski (1965) reconheceram a ocorrência de superfícies interplanálticas designadas como pediplanos (Pd3, Pd2 e Pd1). Justus (1985) reconheceu, nas regiões norte e noroeste do estado do Paraná, a ocorrência de uma superfície de cimeira e três interplanálticas designadas como Superfícies Interplanálticas I, II e III.

De forma geral, não são facilmente observáveis os indícios relacionados à fase de pediplanação e, atualmente, as rochas estão recobertas por uma cobertura pedológica 
espessa. Para Justus (1985), essas superfícies foram retrabalhadas pelas oscilações climáticas quaternárias, sofrendo os efeitos das alternâncias de períodos úmidos e secos.

Assim, no oeste do Paraná, diversos estudos na perspectiva da relação solo-relevo foram e estão sendo realizados. No noroeste do estado, destacam-se aqueles que buscam correlacionar o comportamento dos sistemas pedológicos frente aos processos erosivos de gênese hídrica (NAKASHIMA, 1999; GASPARETTO, 1999; CUNHA, 2002; ANDRADE, 2005; ROCHA, 2016; BARREIROS, 2013; BATISTA, 2018; e SANCHES, 2018). Há, ainda, alguns que buscam o entendimento das relações entre morfogênese, pedogênese e circulação hídrica, fazendo uso de técnicas da micropedologia e/ou datação de materiais da superfície (MAGALHÃES, 2013; COUTO, 2015; e FUMIYA, 2017).

Nesse contexto, esse trabalho busca colaborar com o entendimento da dinâmica geomorfológica dessa região do estado, tendo como estudo de caso a bacia do Rio Taturi.Situada no divisor hidrográfico entre as bacias do Paraná III e do Rio Piquiri, constituise de terrenos que se posicionam na transição entre as rochas ígneas da Formação Serra Geral e as sedimentares da Formação Caiuá.

Bade (2014) e Sanches (2018) avaliam que as variações geológicas encontradas na área de estudo condicionam as diferenciações pedológicas locais. Bigarella e Mazuchowski (1985), assim como, mais recentemente, Goulart e Santos (2014), discutem a suscetibilidade da Formação Caiuá no que se refere ao desenvolvimento dos processos erosivos.

Desta maneira, tem-se como objetivo avaliar o relevo local, suas características e feições, buscando identificar as inter-relações entre as litologias, feições lineares vinculadas a fraturas e falhas e a organização da rede fluvial. Para obter dados que possibilitassem atender esse objetivo, foram realizados diversos mapeamentos morfométricos do relevo, mapeamento dos lineamentos e de suas direções predominantes, assim como uma carta geomorfológica. Tais mapeamentos visam suprir a necessidade de documentos cartográficos geomorfológicos de detalhe na região, sendo as informações existentes limitadas a escalas de pequeno detalhe. Além disso, buscou-se avaliar se as técnicas cartográficas propostas são adequadas ao cenário desse setor do estado.

Desse modo, considera-se que a bacia do Rio Taturi apresenta certas características relacionadas a contatos litológicos, entre os pacotes sedimentares com os afloramentos vinculados aos derrames basálticos, que se assemelham à região oeste do estado do Paraná, constituindo estudo de caso que representa esse setor. Assim, compreender o comportamento espacial das drenagens e suas interações com as variações litológicas e com os lineamentos se torna de suma importância, pois tais interações determinam a potencialidade erosiva dos terrenos e a velocidade pela qual a evolução desses ocorre. 


\section{ÁREA DE ESTUDO}

A bacia do Rio Taturi drena parte dos terrenos dos municípios de Guairá e Terra Roxa (Figura 1). A região posiciona-se, segundo o Atlas Geomorfológico do Estado do Paraná (MINEROPAR, 2006), na unidade Guairá, caracterizada por relevo plano, com pouquíssimas variações altimétricas, embora ocorram variações nas morfologias e na disposição e direcionamento da rede de drenagem. (BADE, 2014; e SANCHES, 2018). Ademais, o Rio Taturi, principal curso hídrico da área de estudo, possui seu nível de base no Rio Paraná, configurando-se como um importante afluente desta bacia hidrográfica.

Figura 1: Localização da bacia hidrográfica do Rio Taturi, região Oeste do Paraná

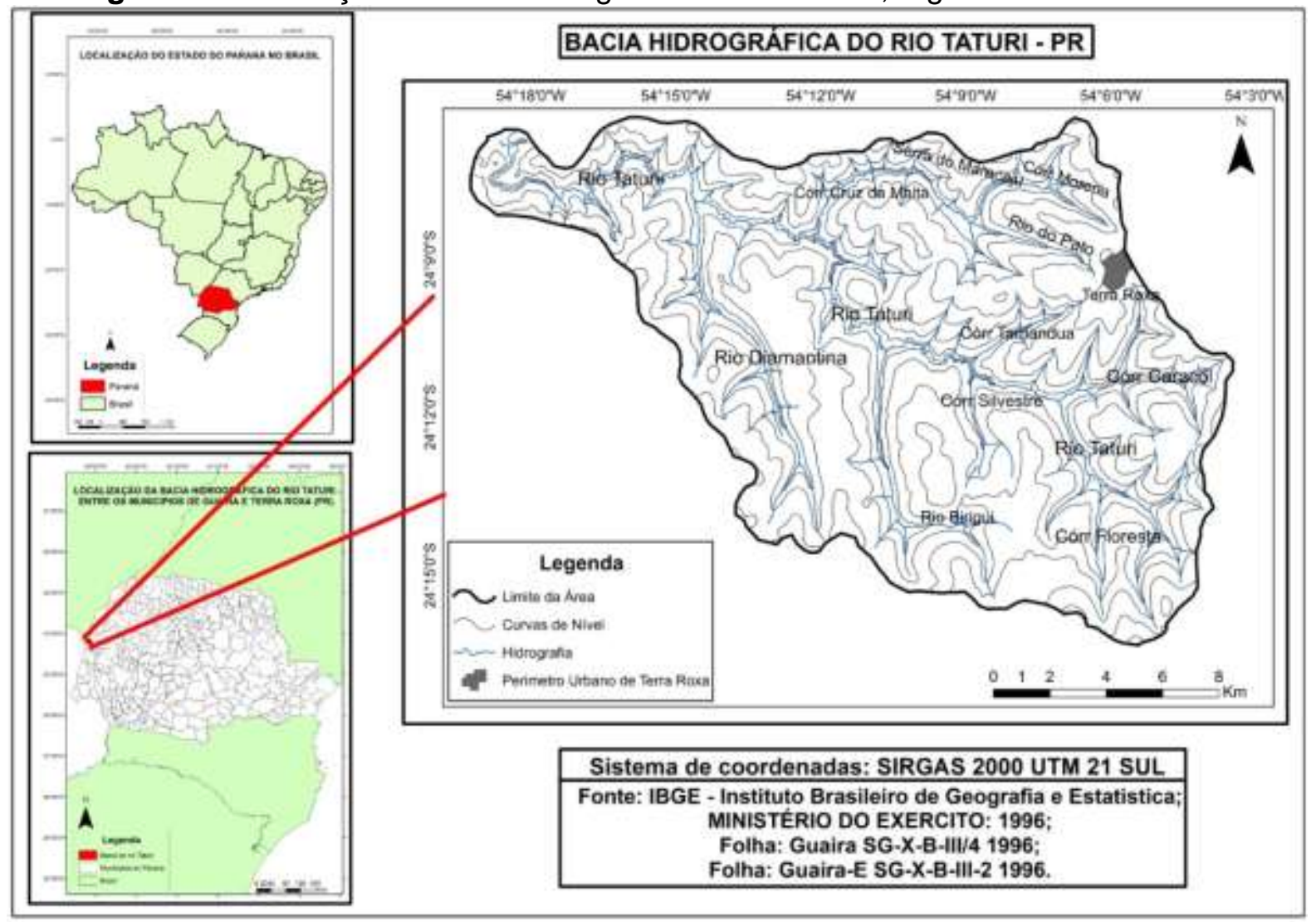

Elaborado pelos autores (2021).

O recorte geográfico desta pesquisa se insere dentro dos limites da Bacia Sedimentar do Paraná, caracterizando-se pelo predomínio, no setor sul e oeste, da Formação basáltica Serra Geral e, a norte e leste, da Formação arenítica Caiuá (Figura 2).

A Formação Serra Geral apresenta grandes derrames basálticos como produto da separação entre os continentes americanos e africanos (BRITO, 1979; e MACHADO et al., 2005). Na região da unidade Guaíra, são encontradas rochas vulcânicas do grupo Paranapanema, com uma alta concentração de titânio. As rochas deste grupo são mais 
encontradas na região setentrional da Bacia Sedimentar, abrangendo todo o oeste do estado do Paraná. (MACHADO et al., 2005).

Figura 2- Litologia da bacia do Rio Taturi (PR)

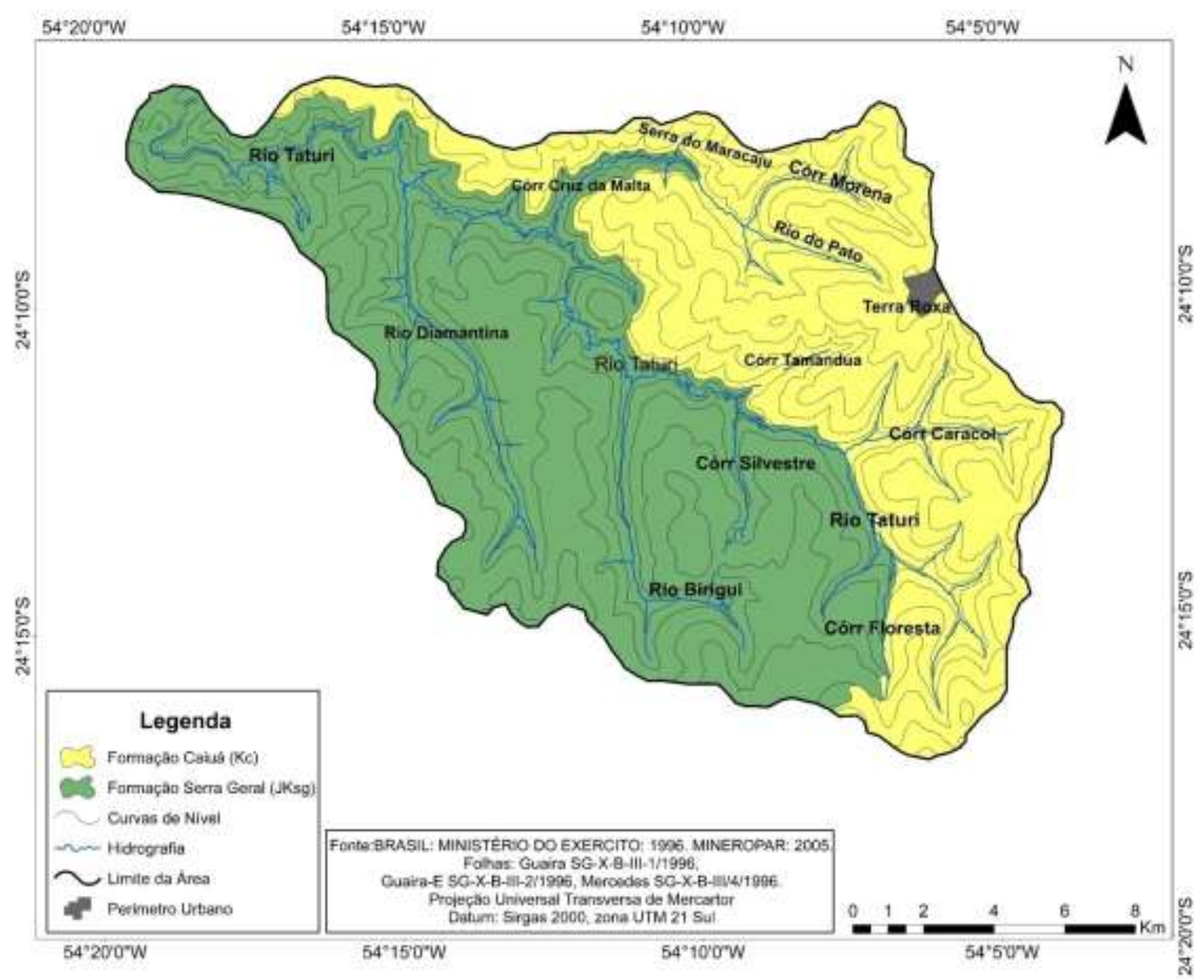

Elaborado pelos autores (2021).

A Formação Caiuá, originária da sedimentação cretácea suprabasáltica do interior da Bacia do Paraná, promovida por deposição eólica, caracteriza-se por arenitos finos a médios de coloração variada, sendo mais avermelhada próxima aos basaltos e arroxeada em outras posições, com grãos arredondados e estratificação cruzada. (BIGARELLA; MAZUCHOWSKI, 1985).

Fernandes e Coimbra (1994) revisaram a estratigrafia e o contexto geológico de sedimentação do Deserto Caiuá, dividindo-o em várias formações geneticamente relacionadas e correspondentes a distintos subambientes. Todavia, para esta pesquisa, optou-se em manter a classificação de Formação Caiuá, pertencente ao Grupo Bauru, visto que o documento cartográfico que mapeia a distribuição das litologias na área (ITGC, 2018) não disponibiliza detalhes que permitam identificar as várias formações que, teoricamente, comporiam o Grupo Caiuá. 
A variação geológica condiciona também solos distintos, oriundos de suas respectivas formações. Os solos provenientes da Formação Serra Geral são mais bem desenvolvidos, mais profundos e mais ricos em nutrientes quando comparados aos solos de origem arenítica. Os solos oriundos da Formação Caiuá são mais suscetíveis aos processos erosivos, possuindo horizontes menos desenvolvidos e, quando comparados ao solo de origem basáltica, possuem também menor concentração de nutrientes. Com isso, a variabilidade pedológica se reflete em variações geomorfológicas ao longo da bacia, afetando aspectos diversificados por toda a sua extensão (GUERRA; BOTELHO, 1998; BUENO; CUNHA; BORTOLUZZI, 2018; e BATISTA, 2018).

Quanto ao clima, a área de estudo apresenta um clima subtropical úmido mesotérmico, de acordo com a classificação climática de Köppen-Geiger. Este clima condiciona chuvas mais intensas e concentradas no período do verão. A temperatura média anual oscila entre os $22^{\circ}$ e $23^{\circ}$ e a pluviosidade varia entre os 1400 e 1600 milímetros por ano (IAPAR, 1994; MAACK; 2012; BUENO; CUNHA; e BORTOLUZZI, 2018).

\section{METODOLOGIA}

O material cartográfico foi gerado por meio automático, pelo software ArcGis, em sua versão 10.2.2. As curvas de nível foram coletadas e construídas a partir das cartas topográficas, possuindo 20 metros de equidistância. Os cursos hídricos também foram traçados a partir das cartas topográficas, assim como a obtenção das toponímias. Foram utilizadas as seguintes cartas topográficas: Guaira (SG-X-B-III-1), Guaira-E (SG-X-B-III-2) e Mercedes (SG-X-B-III/4), elaboradas pelo Ministério do Exército, em 1996, e disponíveis no ITCG (Instituto de Terras, Cartografia e Geologia do Paraná), em escala 1:50.000.

\section{Carta Clinográfica}

A carta clinográfica mostra dados pertinentes à topografia local, identificando áreas cuja inclinação representa potencial fragilidade do relevo (DE BIASI, 1992). Para sua elaboração foram utilizadas as curvas de nível e os cursos hídricos, utilizando procedimento automático disponível no software ArcGis.

As classes de declividade respeitaram princípios colocados por De Biasi (1992), o qual aponta que estas podem ser elaboradas de acordo com as necessidades do autor (Quadro 1). Assim, como o relevo local é marcado por baixos declives, fez-se a opção por detalhar os valores inferiores, buscando avaliar as pequenas diferenças, estabelecendo as classes de 0 a $2 \%$ e de 2 a 5\% (PINTON; CUNHA, 2015). Além disso, utiliza-se o limite de $12 \%$, o qual se 
constitui no limite para a mecanização agrícola (DE BIASI, 1992). O limite superior, marcado em $20 \%$, se deve também as características da área, a qual não apresenta declives superiores a esse valor.

Quadro 1- Classes de declividade e suas características principais

\begin{tabular}{|c|c|}
\hline CLASSES DE DECLIVIDADE & CARACTERIZAÇÃO \\
\hline $0 \% \mathrm{l}-2 \%$ & $\begin{array}{c}\text { Áreas onde há possibilidade de alagamento } \\
\text { (ZANATTA; LUPINACCI; BOIN, 2019), assim } \\
\text { como setores planos de topo. }\end{array}$ \\
\hline $2 \% \mathrm{l}-5 \%$ & $\begin{array}{c}\text { Áreas ainda suscetíveis a alagamentos e de } \\
\text { intenso uso agrícola. (PINTON; CUNHA, 2015; } \\
\text { STEFANUTO; LUPINACCI, 2019). }\end{array}$ \\
\hline $5 \% \mathrm{l}-12 \%$ & $\begin{array}{c}12 \% \text { - Limite para o uso da mecanização no } \\
\text { trabalho agrícola. (DE BIASI, 1992). }\end{array}$ \\
\hline $12 \% \mathrm{l}-20 \%$ & $\begin{array}{c}\text { Áreas com baixo aproveitamento agrícola } \\
\text { devido a declividade. (DE BIASI, 1992; } \\
\text { STEFANUTO; LUPINACCI, 2019). }\end{array}$ \\
\hline
\end{tabular}

Elaborado pelos autores (2021).

\section{Carta de Densidade de Drenagem}

Como afirma Hubp (1988), a carta de densidade de drenagem demonstra como a frequência de cursos fluviais em uma área pode influenciar as dinâmicas do relevo local, refletindo parâmetros associados ao regime hidrográfico, ao tipo de rocha e estrutura local, relacionando-se com os processos erosivos fluviais e gravitacionais.

Para a elaboração desta carta, foram utilizados os shapes do limite da área de estudo e da rede de drenagem. Com isso, foi criada uma base quadriculada, usando a ferramenta conhecida como Fishnet, de tamanho $1200 \times 1200$ (pixels), pois com este tamanho, segundo testes realizados, os detalhes relevantes da região ficam evidenciados na carta. Depois de criada a malha quadriculada, foi quantificada a extensão dos cursos fluviais em cada quadrícula da malha. A densidade de drenagem foi pela divisão entre o comprimento total dos segmentos de drenagem em cada quadrícula pela área da mesma. Conforme propõe Hubp (1988), o valor encontrado em cada quadricula foi atribuído a um ponto central em cada célula, possibilitando a sua interpolação. A técnica de interpolação utilizada foi a linear, a partir da ferramenta "create tin", visto que, como se tratava de malha regular de dados, considerou-se que essa técnica, teoricamente mais simples, permitia avaliar de forma satisfatória a variação da densidade de drenagem na bacia. 


\section{Carta de Profundidade de Drenagem}

Para Hubp (1988), a profundidade de drenagem se diferencia da densidade de drenagem por considerar as diferenças altimétricas entre o talvegue e o divisor de águas. Desta maneira, segundo o autor, a profundidade de drenagem é um reflexo temporal da esculturação do relevo, variando sua intensidade de acordo com as condições litológicas, tectônicas e climáticas locais.

Para a elaboração deste documento, foram utilizados os shapes do limite da área de estudo e das curvas de nível. A proposta elaborada por Hubp (1988) exigiu que fosse criada uma malha quadriculada, procedimento realizado de forma idêntica àquele descrito anteriormente para a carta de densidade de drenagem. Usando o layer da malha quadriculada, obtiveram-se os valores da maior e da menor altitude, dentro de cada célula, a partir das curvas de nível. A profundidade de drenagem foi obtida pela diferença entre as cotas altimétricas de maior e menor valor. Com a amplitude já calculada, foi possível vincular tais valores a um ponto central das quadrículas, seguindo a proposta sugerida por Hubp (1988). Foi realizada a interpolação linear entre os valores atribuídos aos pontos. Após executar o processamento, foi elaborado um mapa temático com uma sequência de cores correspondentes à variação do fenômeno, atribuída automaticamente pelo software utilizado.

\section{Carta de Lineamentos}

Como evidenciam Soares e Fiori (1976), eventos de subsuperfície podem ocasionar lineamentos como produtos, sendo estes representados por altos topográficos (em cristas alinhadas) ou baixos topográficos (drenagens e vales). Assim, a análise das fotografias aéreas e de cartas topográficas possibilita ao pesquisador identificar tais feições do relevo, as quais permitem avaliar o impacto das forças endógenas na organização dos terrenos estudados (SOARES; FIORI, 1976; e MOURA; MARQUES NETO, 2015).

Desta forma, como propõe Soares e Fiori (1976), foi realizada a interpretação dos segmentos lineares nas cartas topográficas (Guaira, Guaira-E e Mercedes). Os lineamentos foram traçados a partir de áreas de interesse, onde um rio, por exemplo, apresentava traçados retilíneos e mudanças bruscas de sentido, perfazendo ângulos próximos a 90. Esses lineamentos foram complementados com o mapa da MINEROPAR (2001), em escala 1:250.000, que apresenta os lineamentos em escala regional. A partir dos lineamentos compilados da MINEROPAR (2001) e daqueles traçados nesse trabalho, foram elaborados diagramas de rosetas no programa Spring, em sua versão 5.5.5. 


\section{Carta Geomorfológica}

Para a elaboração da carta geomorfológica foram utilizadas as propostas de Tricart (1965) e de Verstappen e Zuidam (1975), em escala de análise 1:50.000. Conforme proposto por Tricart (1965), a carta geomorfológica elaborada apresenta os seguintes dados (Quadro 2): morfometria, mapeada através das curvas de nível e hidrografia; morfografia, representada pelos símbolos que identificam as diversas formas de relevo (rupturas topográficas, formas de vertentes e de vales e feições erosivas, entre outras) e morfogênese, apresentada por meio do agrupamento dos símbolos, evidenciando os processos originários das formas (feições de origem denudativa, feições resultantes da ação das águas correntes e modelado antrópico). Além disso, o autor enfatiza que, para a excelência na produção das informações contidas na carta, é necessário apresentar dados litológicos e das feições estruturais, demonstrando o arcabouço estrutural do relevo. Assim, a cronologia das formas não foi identificada, foi apresentada somente a cronologia dos materiais, isto é, das formações litológicas que sustentam as formas de relevo.

Como base para o desenvolvimento desta carta, utilizaram-se as fotografias aéreas disponibilizadas pelo Instituto de Terras, Cartografia e Geologia do Paraná (ITGC), em escala de 1:25.000, registradas em 1980. Essas fotografias aéreas, apesar de mais antigas, permitiram obter dados detalhados do relevo da bacia, fazendo uso da estereoscopia. Em um terreno plano como o estudado, a estereoscopia constitui-se em instrumento importante para identificar a morfologia, permitindo sua análise de forma conjunta com os dados morfométricos e dos lineamentos. Dessa forma, considerou-se que esses dados de detalhe do relevo foram suficientes para atender ao objetivo da pesquisa, o qual não exige dados atuais, mas sim dados de qualidade da morfologia dos terrenos que permitam avaliar a influência das litologias e dos lineamentos na organização do relevo.

Com o uso do software Stereo Photo Maker e com base nos procedimentos propostos por Souza e Oliveira (2012), foram gerados anáglifos, que possibilitaram a análise das fotografias aéreas em 3D. A elaboração e criação dos símbolos (Quadro 2) utilizados na carta geomorfológica foi realizada de acordo com as técnicas propostas por Paschoal, Conceição e Cunha (2010) e, neste caso, foram destacados os símbolos referentes aos processos erosivos, mapeados em vermelho, e das feições que indicam alteração no equilíbrio dinâmico, incluindo as rupturas topográficas. 
Quadro 2 - Estruturação da legenda que compõe a carta geomorfológica da bacia do Rio

\begin{tabular}{|c|c|c|c|c|c|}
\hline GRUPOS & \multicolumn{3}{|c|}{ ELEMENTOS/FORMAS } & SÍMBOLO & FONTE* \\
\hline \multirow{2}{*}{$\begin{array}{l}\text { Dados } \\
\text { litológicos }\end{array}$} & \multicolumn{2}{|c|}{ Cretáceo Superior } & $\begin{array}{l}\text { Formação Caiuá } \\
(\mathrm{Kc})\end{array}$ & & 4 \\
\hline & \multicolumn{2}{|c|}{ Jurássico-Cretáceo } & $\begin{array}{l}\text { Formação Serra } \\
\text { Geral (JKsg) }\end{array}$ & & 4 \\
\hline \multirow{7}{*}{ 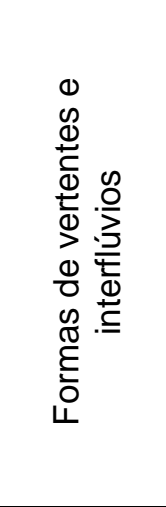 } & \multirow{2}{*}{ Vertente } & \multicolumn{2}{|c|}{ Côncava } & $\forall$ & 2 \\
\hline & & \multicolumn{2}{|c|}{ Convexa } & $\infty$ & 2 \\
\hline & \multirow{4}{*}{$\begin{array}{l}\text { Formas } \\
\text { localizadas }\end{array}$} & \multicolumn{2}{|c|}{ Colo topográfico } & 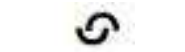 & 1 \\
\hline & & \multicolumn{2}{|c|}{ Erosão laminar } & th & 3 \\
\hline & & \multicolumn{2}{|c|}{ Sulcos erosivos } & wols & 3 \\
\hline & & \multicolumn{2}{|c|}{ Ravina } & $=$ & 1 \\
\hline & $\begin{array}{l}\text { Feições } \\
\text { topográficas }\end{array}$ & \multicolumn{2}{|c|}{ Curvas de nível } & & 4 \\
\hline \multirow{8}{*}{ 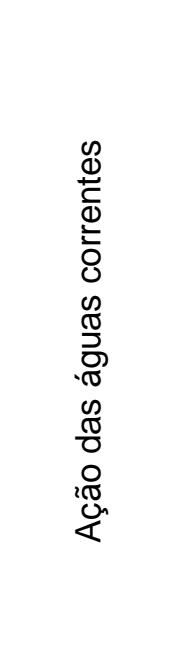 } & \multirow{2}{*}{$\begin{array}{c}\text { Feições } \\
\text { hidrográficas }\end{array}$} & \multirow{2}{*}{$\begin{array}{l}\text { Canais de } \\
\text { drenagem }\end{array}$} & Fluvial & & 4 \\
\hline & & & Pluvial & & 4 \\
\hline & \multirow{2}{*}{$\begin{array}{l}\text { Formas de } \\
\text { acumulação }\end{array}$} & \multicolumn{2}{|c|}{$\begin{array}{l}\text { Acumulação de Planície e Terraço } \\
\text { fluvial }\end{array}$} & & 1 \\
\hline & & \multicolumn{2}{|c|}{ Leque aluvial } & & 1 \\
\hline & \multirow{4}{*}{$\begin{array}{l}\text { Modelado de } \\
\text { entalhe }\end{array}$} & \multirow{2}{*}{$\begin{array}{l}\text { Ruptura } \\
\text { topográfica }\end{array}$} & Suave & & 2 \\
\hline & & & Abrupta & & 2 \\
\hline & & \multirow{2}{*}{$\begin{array}{l}\text { Fundos } \\
\text { de Vale }\end{array}$} & Plano & & 2 \\
\hline & & & Encaixado & & 2 \\
\hline \multirow{2}{*}{$\begin{array}{l}\text { Modelado } \\
\text { antrópico }\end{array}$} & \multicolumn{3}{|c|}{ Terraços agrícolas } & $\pi$ & 1 \\
\hline & \multicolumn{3}{|c|}{ Represas } & & 4 \\
\hline
\end{tabular}

Fonte: * 1 - Tricart (1965); 2 - Verstappen; Zuidan (1975); 3 - Adaptação; 4 - Convenção cartográfica. Elaborado pelos autores (2021).

\section{RESULTADOS}

A bacia do Rio Taturi possui uma variação altimétrica pequena ao longo de sua extensão, de cerca de 220 metros. No entanto, o mapeamento da declividade do terreno (Figura 3) demonstra variações de inclinação do perfil, denotando áreas de declive mais intenso.

Como fica evidenciado pela carta clinográfica (Figura 3), a região cujo domínio geológico pertence aos arenitos da formação Caiuá (Figura 2), possui de forma predominante uma declividade mais acentuada, quando comparada com a região de 
domínio pertencente aos basaltos. Esta característica ocorre devido a uma fragilidade maior do material arenítico aos processos denudativos, que é significativamente mais acentuada quando comparada com aos derrames basálticos da Formação Serra Geral. Desta forma, há uma maior ocorrência da classe de 0 a $2 \%$ nos setores em que os derrames basálticos dominam, demonstrando uma variação da declividade de forma sutil, evidenciando um setor predominantemente plano.

Figura 3 - Carta clinográfica da bacia do Rio Taturi (PR)

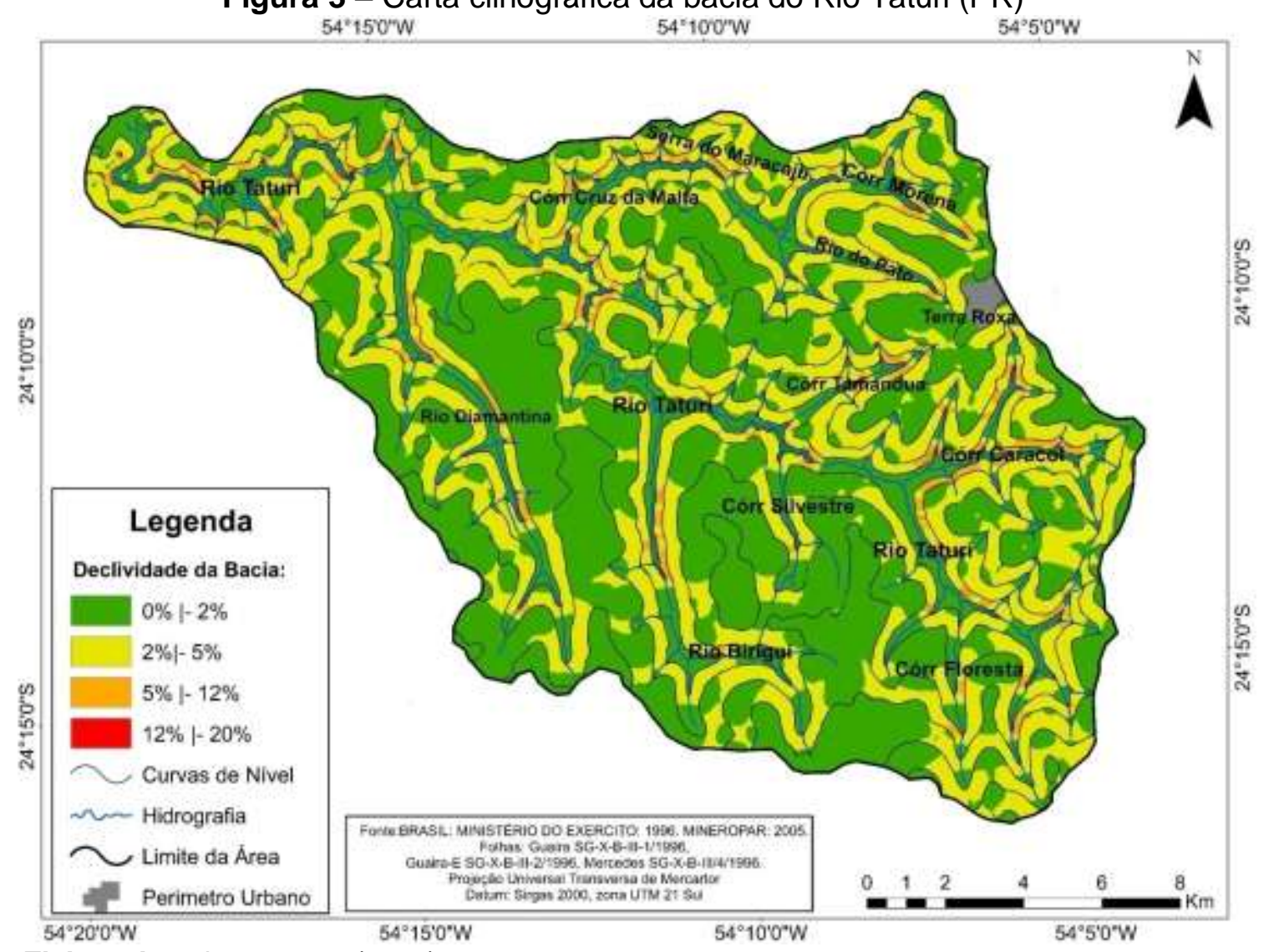

Elaborado pelos autores (2021).

Todavia, no setor jusante da bacia do Rio Taturi constata-se uma declividade mais alta, marcada pelo predomínio da classe de $2 \%$ a $5 \%$ de inclinação, e em alguns pontos da classe $5 \%$ a $12 \%$, sendo este o setor mais inclinado da área de pesquisa. Uma hipótese para este setor apresentar-se com estas características diz respeito à energia do canal, que escava os terrenos de forma mais pronunciada logo após a confluência com o Rio Diamantina (Figura 3).

Assim, de forma geral, a bacia não possui uma declividade acentuada, mas apresenta especificidades bem localizadas, que se diferenciam dos demais setores. Desta maneira, a região arenítica é a que mais apresenta setores acima dos $2 \%$ de declividade, variando até os $12 \%$. Nas regiões basálticas, a oeste da bacia, constata-se que há um domínio 
significativo da classe de até $2 \%$ de declividade, com exceções localizadas variando até os $12 \%$ e pontualmente, no setor de foz, de até $20 \%$.

A carta de densidade de drenagem (Figura 4) aponta classes intermediárias nas áreas de ocorrência dos arenitos Caiuá, mesmo sendo possível observar um número significativo de interflúvios e de nascentes, que por consequência intensificam a dissecação do relevo nessa porção da bacia, expressa pela concentração de curvas de nível.

Figura 4 - Carta de densidade de drenagem da bacia do Rio Taturi (PR)

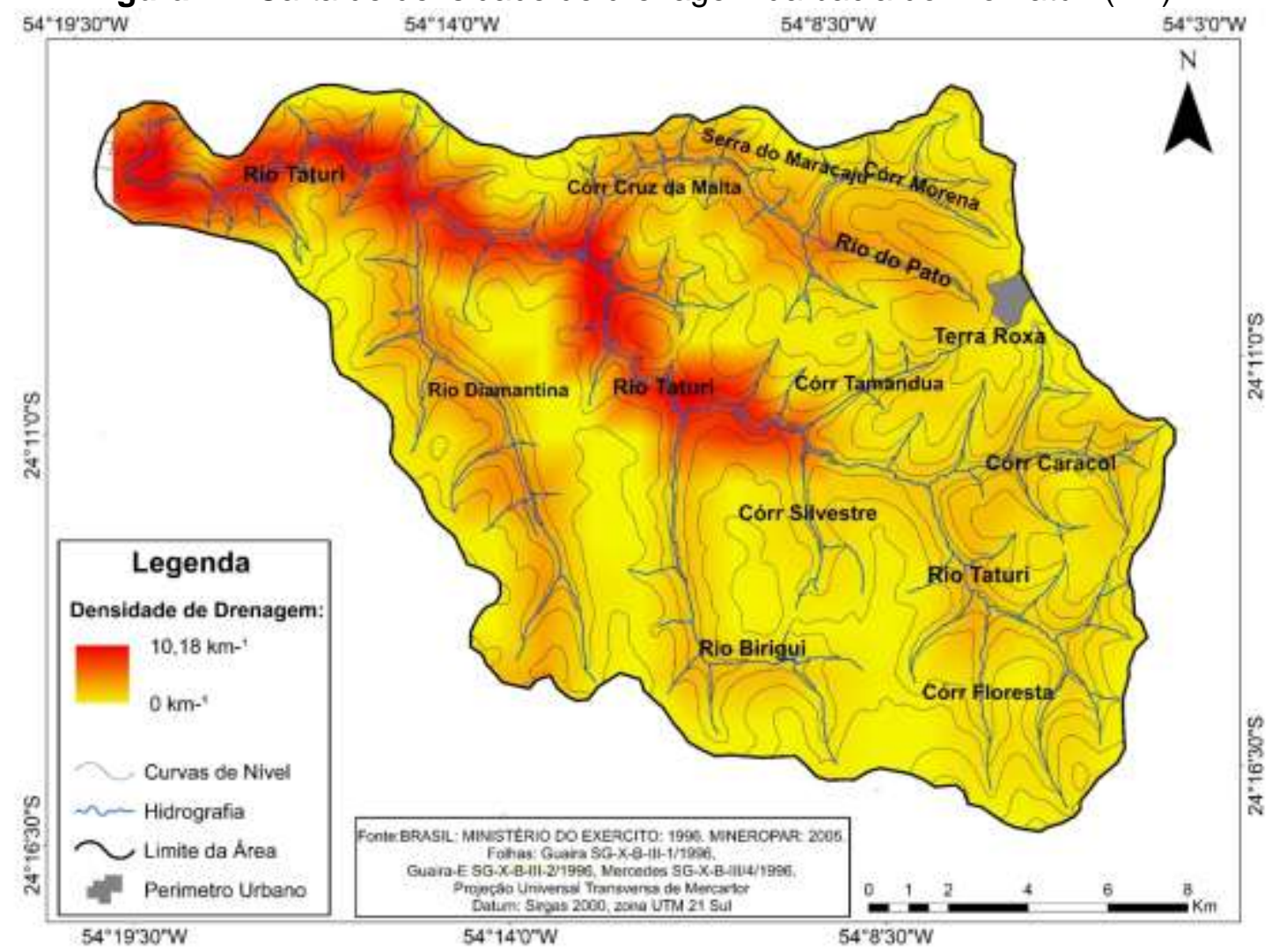

Elaborado pelos autores (2021).

No entanto, mesmo que a região de afloramento da Formação Caiuá possua um número elevado de canais fluviais, os valores mais elevados de densidade de drenagem são encontrados na porção de domínio basáltico. Os valores mais altos de densidade de drenagem se concentram sobre o médio e baixo curso do Rio Taturi, área de destaque pelo contato entre as distintas formações geológicas e pelo alto nível de desvios abruptos do canal fluvial. Assim, as diversas sinuosidades do canal principal geraram os maiores valores de densidade de drenagem. Tais sinuosidades obedecem aos planos de fraturamento dos basaltos, os quais condicionam o curso principal.

Embora estes planos de fraturamento sejam encontrados principalmente ao longo do curso principal do Rio Taturi, afluentes, como o Rio Diamantina, Rio Birigui e Córrego Cruz 
da Malta, também apresentam influências significativas destes fraturamentos, possuindo a Formação Serra Geral como base geológica.

A energia potencial dos rios e a variação do material geológico também criaram diferenças na profundidade de drenagem (Figura 5). Foi possível constatar que a faixa de transição identificada entre os arenitos e o basalto (Figura 2), a qual ocorre sobre o curso principal do Rio Taturi, apresenta uma profundidade de drenagem bem acentuada. Esse fato ocorre devido a um aprofundamento do canal no contato das litologias. Os contatos litológicos frequentemente são setores de maior fragilidade erosiva devido às diferenças entre os materiais, provocando concentração de escoamento de água em função de mudanças abruptas de permeabilidade.

Figura 5 - Carta de profundidade de drenagem da bacia do Rio Taturi (PR)

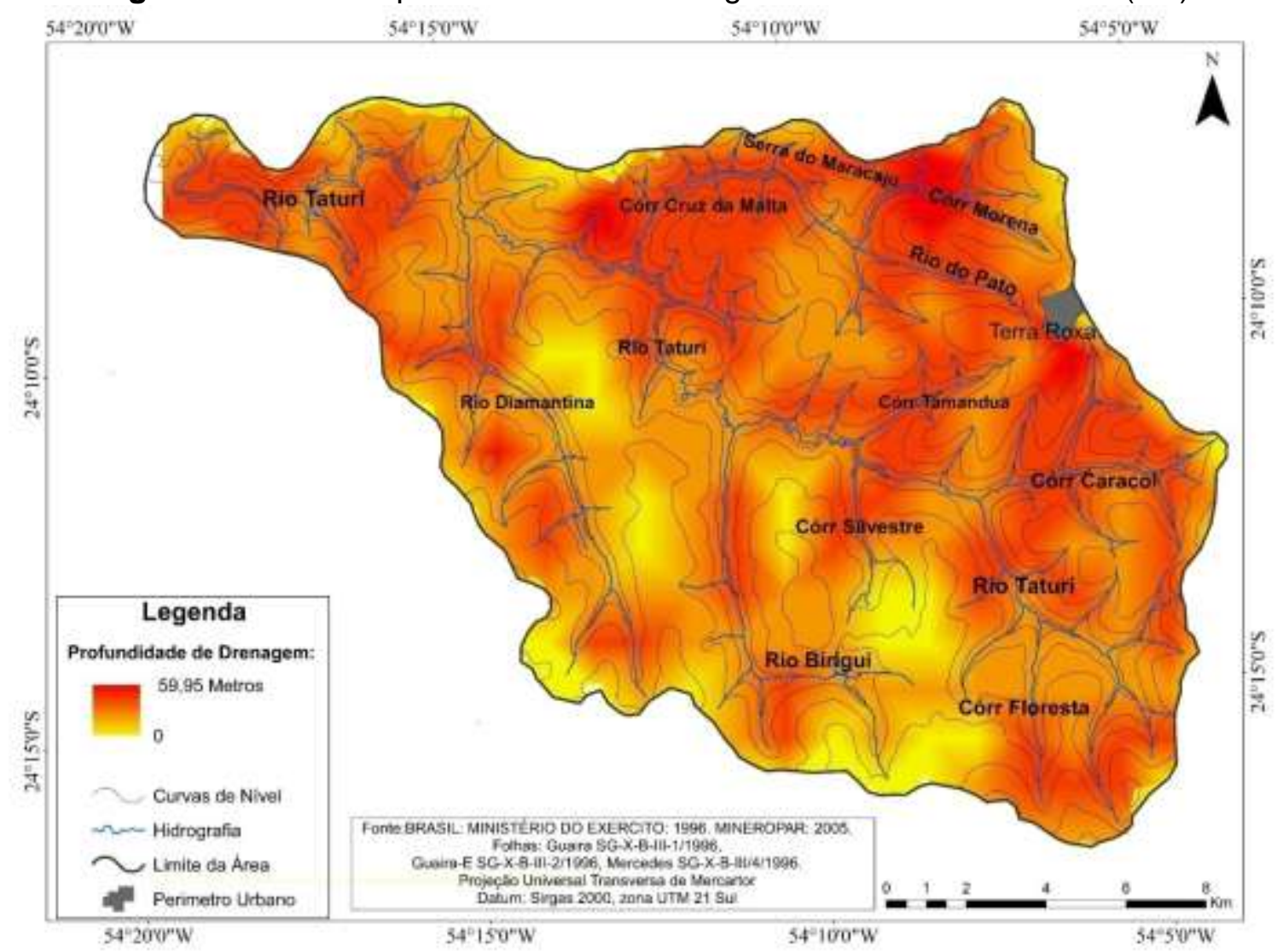

Elaborado pelos autores (2021).

Destaca-se ainda o setor drenado pelo Córrego Cruz de Malta, marcado por elevada profundidade de drenagem e por uma morfologia circular e de cotovelos de drenagem, demonstrando possível influência tectônica, que pode auxiliar a escavação desse córrego e seus afluentes. A região da Serra do Maracaju, que abrange além do Córrego Cruz da Malta, o Córrego da Morena e o Rio da Prata (Figura 5), apresenta uma elevada profundidade de drenagem, fato também encontrado na região do Córrego do Caracol. Destaca-se também a única área urbana no recorte espacial da bacia hidrográfica do Rio 
Taturi, a cidade de Terra Roxa (PR), inserida em um interflúvio marcado por uma elevada profundidade de drenagem.

Os setores com o menor valor de profundidade de drenagem incidem sobre as áreas de domínio basáltico (Figura 5). Fatores endógenos, como a maior resistência do material geológico e menor influência tectônica, podem contribuir para estas características, que estão presentes ao longo dos interflúvios entre os cursos hídricos, como no Rio Birigui, Córrego Silvestre e Rio Diamantina.

Essas características morfométricas do relevo sofrem influência também dos lineamentos identificados na área (Figura 6). Este condicionante endógeno, aliado a forças exógenas naturais, gera canais fluviais que podem exibir traços retilíneos ou com desvios abruptos, atuando como agentes esculturais do relevo (SOARES; FIORI, 1976).

Figura 6 - Lineamentos da bacia do Rio Taturi (PR)

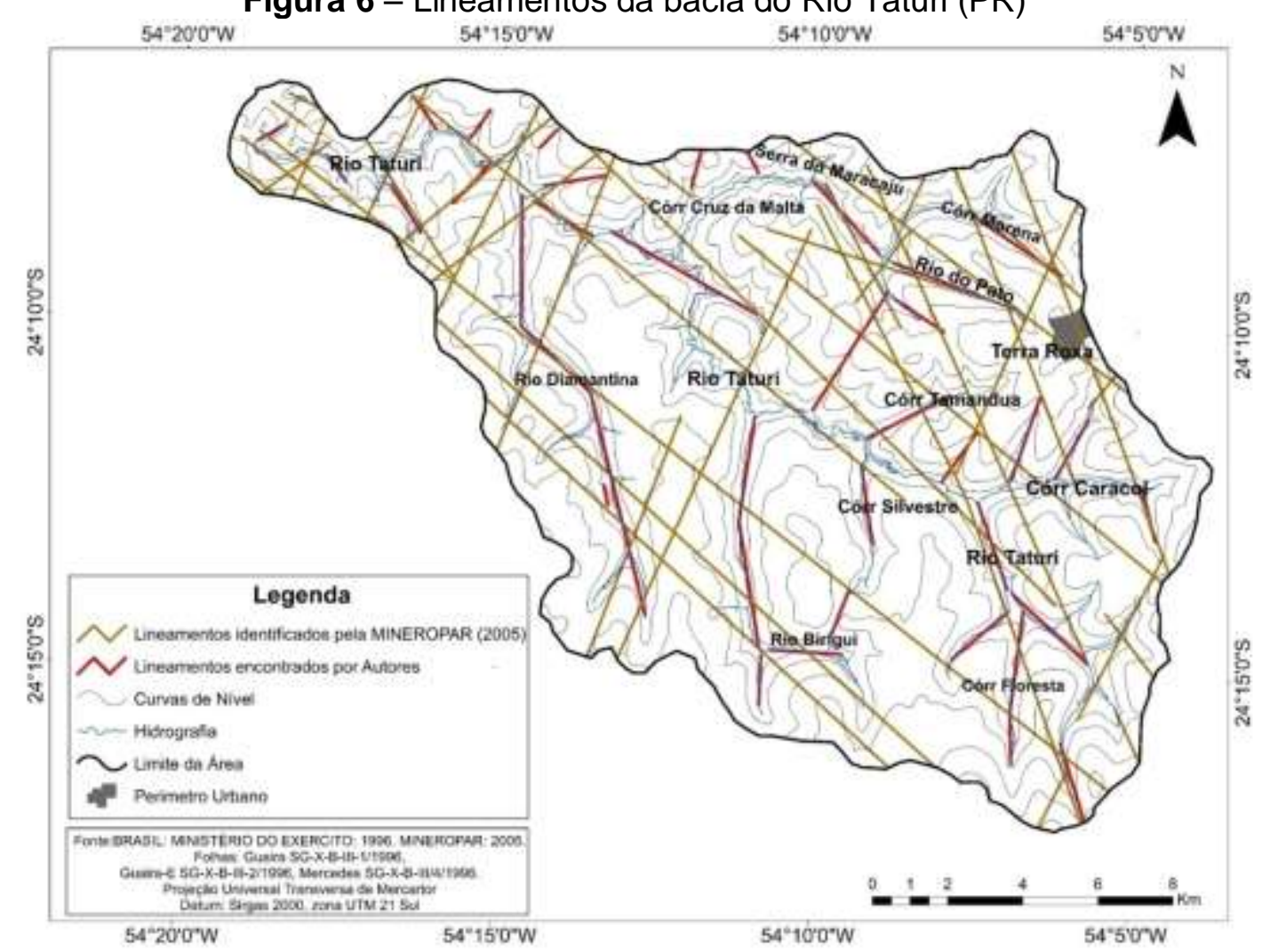

Elaborado pelos autores (2021).

De forma geral, a concentração de lineamentos se apresenta de forma acentuada no setor leste da bacia, abrangendo o Córrego Cruz da Malta e afluentes, assim como as nascentes e todo o curso do Rio Taturi. Ainda, todo este setor apresenta uma densidade de drenagem elevada (Figura 4), e boa parte do entorno destes cursos hídricos apresentam valores elevados de profundidade de drenagem (Figura 5). 
Contudo, alguns canais fluviais, mesmo encaixados em lineamentos, não possuem os maiores valores encontrados na carta de profundidade de drenagem. Os rios Diamantina e Birigui, em conjunto com o Córrego Silvestre, estão inseridos em lineamentos e não apresentam uma profundidade expressiva quando comparada com o restante da bacia, fator que pode ser condicionado pelo material geológico da Formação Serra Geral, presente ao longo de todo o curso destes canais, que pela sua resistência aos processos erosivos não permite o aprofundamento dos canais fluviais. Desta forma, os rios não possuem energia suficiente para esculpirem seus vales de forma expressiva. Ainda, na área de domínio da Formação Serra Geral identifica-se um setor de provável captura de drenagem futura, fomentada por um lineamento entre o Rio Birigui e o Córrego Silvestre.

O curso do Rio Taturi apresenta elevada sinuosidade, conforme apontado pela carta de densidade de drenagem (Figura 4) e pela carta de profundidade de drenagem (Figura 5). Embora tenham sido identificados alguns lineamentos ao longo do curso do Rio Taturi, destacam-se alguns lineamentos identificados pela MINEROPAR (2005), que cortam quase toda a extensão do curso hídrico em direção NO-SE, fato que corrobora com a influência endógena expressiva no caso dessa drenagem.

Quanto às direções, NO-SE se constitui na mais comum encontrada nos lineamentos de topo (Figura 7), mapeados pela MINEROPAR (2005); secundariamente, ocorrem as direções NE-SO e NNO-SSE. Para os lineamentos identificados por este trabalho, a direção mais frequente é NNO-SSE, seguida pelas direções NE-SO e NO-SE, com o aparecimento também da direção N-S.

Figura 7 - Diagrama de rosetas dos lineamentos da bacia do Rio Taturi (PR). Em (A) Lineamentos identificados por MINEROPAR (2005) e em (B) identificados nessa pesquisa

A

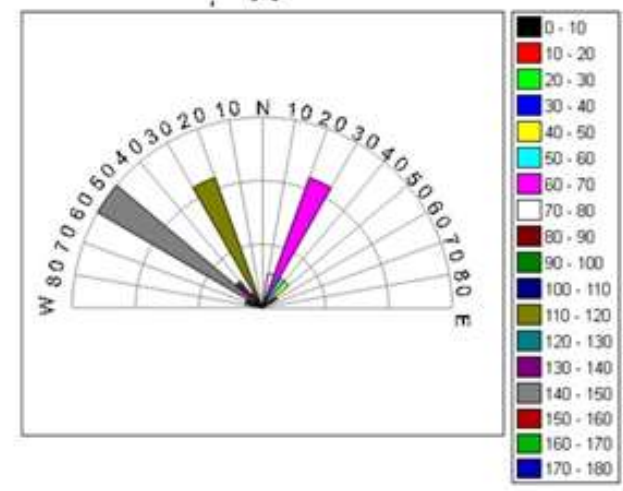

B

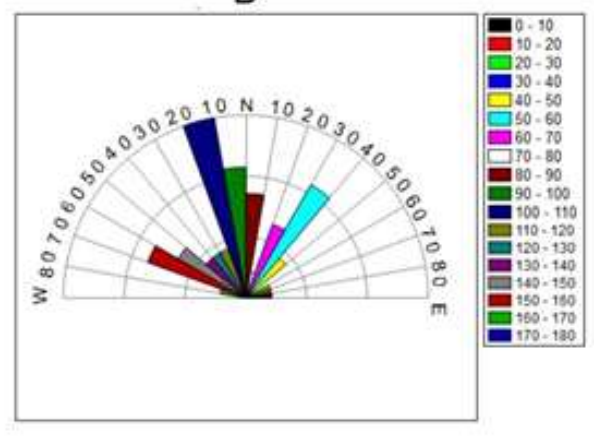

Elaborado pelos autores (2021).

A carta geomorfológica da bacia do Rio Taturi (Figura 8), evidencia a correlação entre as características morfométricas do relevo, o embasamento geológico e a ocorrência de feições erosivas. Constatou-se um número mais elevado de rupturas topográficas e de 
feições erosivas nas áreas de ocorrência da Formação Caiuá, com uma grande concentração de sulcos erosivos, ravinas e de marcas de erosão laminar.

Figura 8 - Carta geomorfológica da bacia do Rio Taturi (PR)

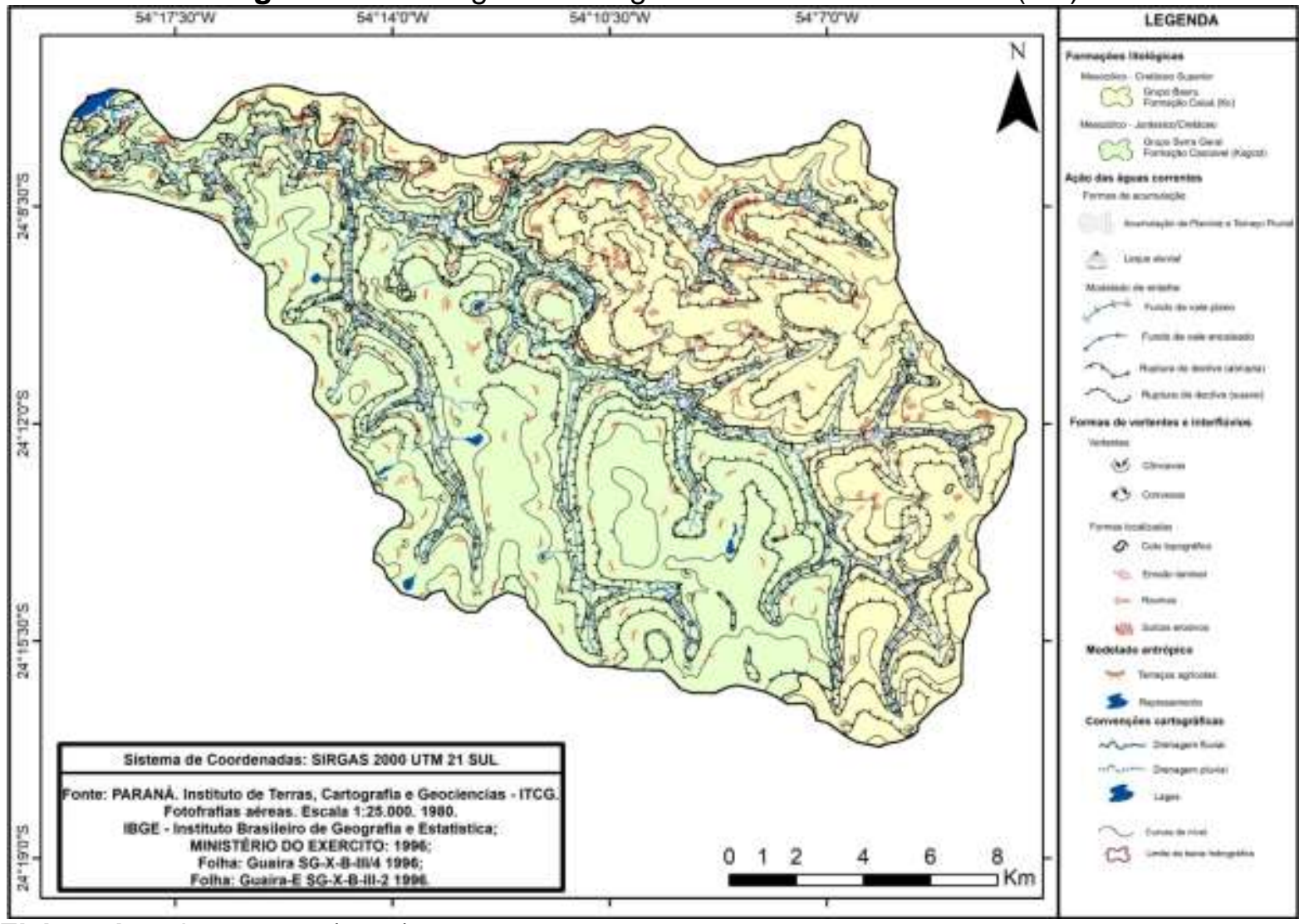

Elaborado pelos autores (2021).

Como exemplo, o interflúvio entre o Córrego Cruz da Malta e o Rio Taturi apresenta a maior concentração de feições erosivas da bacia (Figura 9). Esse setor é marcado pela presença de várias rupturas topográficas, escalonadas, o que também demonstra intensa atividade denudativa, além de inúmeros lineamentos (Figura 6), alta densidade de drenagem (Figura 4) e os níveis mais elevados de profundidade de drenagem (Figura 5), denotando um setor naturalmente instável.

Ainda, a respeito das feições erosivas lineares, a sua grande maioria ocorre na área sustentada pelos arenitos Caiuá. Foram identificados na bacia um total de 111 sulcos e 42 ravinas, sendo que 90 sulcos e 29 ravinas se encontram em área arenítica, e o restante, 21 sulcos e 13 ravinas, em áreas da Formação Serra Geral. Com isso, além das características morfométricas, o embasamento geológico possui uma grande influência na ocorrência de feições erosivas lineares na área estudada.

As áreas de domínio arenítico apresentam também rios com vales do tipo encaixado, possuindo uma maior concentração quando comparada à área de domínio da Formação 
Serra Geral, que exibe pouquíssimos vales do tipo encaixado. Esta característica confere ao sistema fluvial do setor arenítico uma maior capacidade erosiva, que se reflete na maior profundidade de dissecação (Figura 5) e em maior declividade (Figura 3).

Figura 9 - Feições erosivas no interflúvio entre o Rio Taturi e o Córrego Cruz da Malta

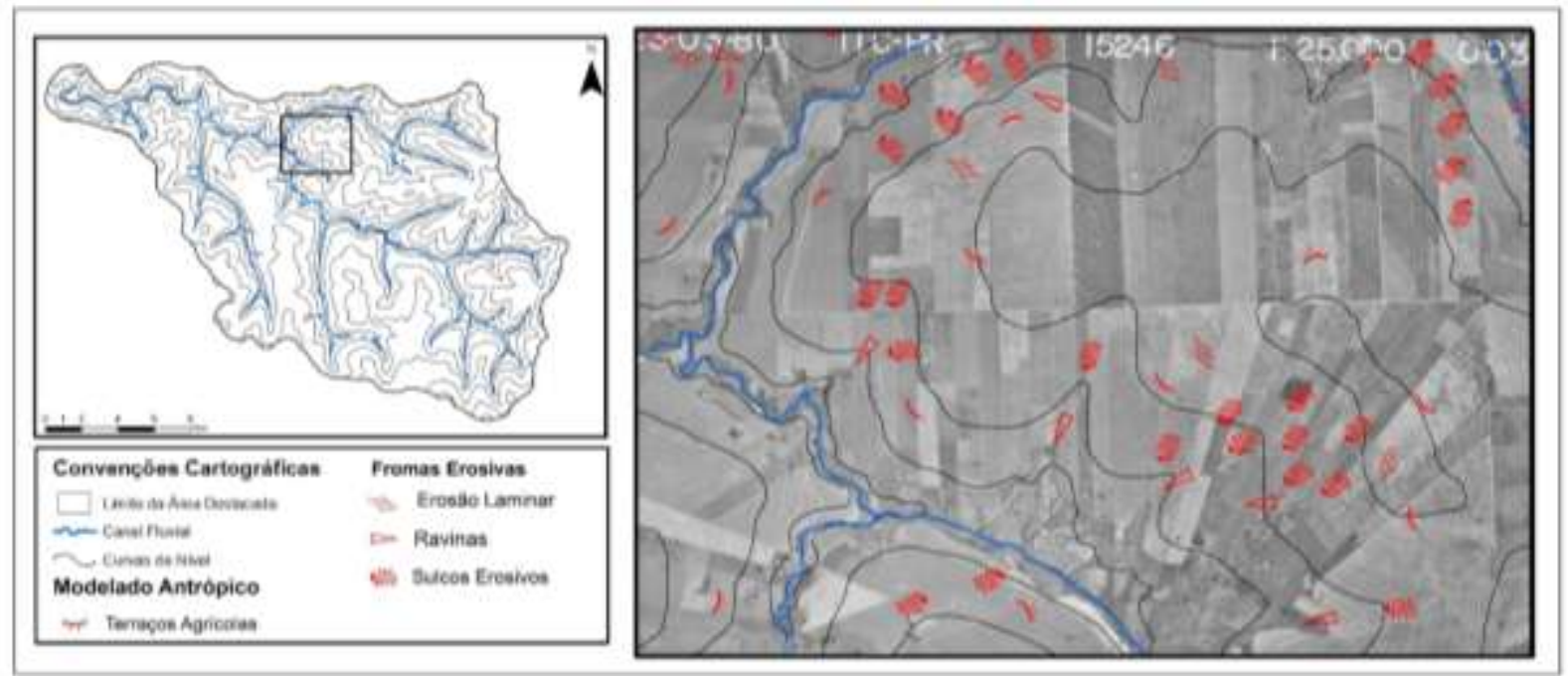

Elaborado pelos autores (2021).

Nas áreas de domínio basáltico, há pouca presença de feições erosivas, sendo identificados inúmeros terraços agrícolas, o que evidencia a vocação desta área para este tipo de uso. Nos terrenos do entorno do médio e baixo curso do Rio Taturi registraram-se inúmeras rupturas de relevo, em sua maioria suaves e bem próximas ao curso fluvial. Neste setor são encontradas grandes áreas de APTF (Acumulação de Planície e de Terraço Fluvial), que podem ser alimentadas pelo aumento dos processos erosivos nas vertentes, que intensifica o escoamento superficial da água e carrega sedimentos para os fundos de vale.

Porém, convém destacar que, como afirmam Bigarella e Mazuchowski (1985), na área de domínio arenítico no oeste do estado do Paraná são comumente encontrados relevos ondulados, de topo aplainado e ligeiramente convexo, que de forma geral formam uma vasta área consideravelmente plana. Esta morfologia é dominante também na área estudada, contudo, como evidenciado pela carta geomorfológica (Figura 8), a bacia do Rio Taturi está sofrendo com um elevado número de feições erosivas, originárias de uma fragilidade natural aliada a uma provável falta de práticas conservacionistas.

Para Guerra e Botelho (1998), as áreas originárias da Formação Caiuá, no oeste do Paraná, foram amplamente utilizadas para atividade agrícola intensa e sem controle estatal nos últimos 70 anos, explorando um solo já vulnerável aos processos erosivos. Desta forma, a ausência de matéria orgânica provocada pelo desmatamento da área aumentou a suscetibilidade dos solos à erosão, principalmente hídrica, rompendo com o equilíbrio 
hídrico e aumentando a erosão linear na área da bacia. Dessa forma, foi possível constatar uma complexa relação entre as questões estruturais, erosivas e antrópicas.

\section{CONSIDERAÇÕES FINAIS}

Evidencia-se que fatores endógenos como a litologia e fraturas e falhas condicionam as feições e características do relevo e dos cursos hídricos. Os setores marcados pelos afloramentos da Formação Serra Geral possuem as menores declividades e os maiores índices de densidade de drenagem, em contraponto aos menores valores de profundidade de drenagem e menor ocorrência de feições erosivas. A influência dos lineamentos neste setor propicia a ocorrência de canais fluviais retilíneos, mas sem um notável aprofundamento de seus vales, e os pequenos fraturamentos marcam a elevada sinuosidade no curso principal do Rio Taturi.

Os setores de ocorrência da Formação Caiuá são marcados pelas maiores declividades, menor índice de densidade de drenagem, profundidade de drenagem acentuada, elevada frequência de lineamentos e um elevado número de feições erosivas, evidenciando um setor naturalmente mais frágil aos processos denudativos, que pode sofrer consequências mais severas do uso da terra sem o correto manejo.

Com isso, as técnicas aplicadas forneceram dados que supriram os objetivos propostos pelo trabalho, evidenciando as características estruturais do relevo e dos cursos hídricos ao longo de toda a bacia. Ainda, os dados detalhados apresentados podem colaborar com o maior entendimento das dinâmicas naturais do oeste do estado.

\section{REFERÊNCIAS}

ANDRADE, José Antônio de. As unidades de paisagens e os sistemas de produção agrícolas no município de Floraí-PR. 2005. Dissertação (Mestrado em Geografia) Universidade Estadual de Maringá, Maringá, 2005.

BADE, Maicol Rafael. Definição e caracterização das unidades de paisagem das bacias hidrográficas do Paraná III (Brasil/Paraguai). 2014. Dissertação (Mestrado em Geografia) - Universidade Estadual do Oeste do Paraná, Marechal Cândido Rondon, 2014.

BARREIROS, André Mateus. Estudo sobre a pedogênese na transição arenitosbasaltos na Bacia do Córrego Gurupá (Floraí/PR). 2013. Dissertação (Mestrado em Geografia) - Universidade de São Paulo, São Paulo, 2013.

BATISTA, Marcelo. Estudo morfopedológico em uma topossequência de solos no município de Terra Roxa-PR. 2018. Dissertação (Mestrado em Geografia) Universidade Estadual do Oeste do Paraná, Marechal Cândido Rondon, 2018.

BIGARELLA, João José; MAZUCHOWSKI, Jorge Zbigniew. Considerações a respeito da evolução das vertentes. Boletim Paranaense de Geografia, Curitiba, n.16 e 17, p.85-116, 1965. 
BIGARELLA, João José; MAZUCHOWSKI, Jorge Zbigniew. Visão integrada da problemática da erosão. Curitiba: Associação de Defesa e Educação Ambiental e Associação Brasileira de Geologia de Engenharia, 1985.

BRITO, Ignacio Machado. Bacias Sedimentares e Formações Pós-paleozoicas do Brasil. Rio de Janeiro: Interciencia,1979.

BUENO, Karoline; CUNHA, José Edézio da; BORTOLUZZI, Leandro Neri. O entendimento da fragilidade ambiental do município de Guairá-Paraná. Caminhos de Geografia, Uberlândia, v. 19, n. 68, p. 81-100, 2018.

COUTO, Edivando Vitor do. Evolução denudacional de longo prazo e a relação solorelevo no Noroeste do Paraná. 2015. Tese (Doutorado em Geografia) - Universidade Federal do Paraná, Curitiba, 2015.

CUNHA, José Edézio. Funcionamento hídrico e suscetibilidade erosiva de um sistema pedológico constituído por Latossolo e Argissolo no município de Cidade Gaúcha-PR. 2002. Tese (Doutorado em Geografia) - Universidade de São Paulo, São Paulo, 2002.

DE BIASI, Mario. A carta clinográfica: Os métodos de representação e sua confecção. Revista do Departamento de Geografia, São Paulo, n. 6, p. 45-60, 1992.

FERNANDES, Luiz Alberto; COIMBRA. Armando Mario. O grupo Caiuá (Ks): Revisão estratigráfica e contexto deposicional. Revista Brasileira de Geociências, São Paulo, n. 24, p. 164-176, 1994.

FUMIYA, Marcel Hideyuki. Gênese dos ferricretes e sua relação com transformações da paisagem no Noroeste do Paraná. 2017. Tese (Doutorado em Geografia) - Universidade Federal do Paraná, Curitiba, 2017.

GASPARETTO, Nelson Vicente Lovatto. As formações superficiais no noroeste do Paraná e sua relação com o Arenito Caiuá.1999. Tese (Doutorado em Geologia) Universidade de São Paulo, São Paulo, 1999.

GOULART, Adriano Ávila; SANTOS, Leandro José Cordeiro. Evolução temporal e espacial das paleovoçorocas presentes no município de Loanda/PR. Revista Geonorte, Edição Especial, v.10, p. 81-86, 2014.

GUERRA, António José Teixeira; BOTELHO, Rosangela Garrido Machado. Erosão e solos. In: GUERRA, António José Teixeira; CUNHA, Sandra Batista da. Geomorfologia do Brasil. Rio de Janeiro: Bertrand Brasil, 1998. p. 181-220.

HUBP, José Lugo. Elementos de Geomorfologia Aplicada (Metodos Cartograficos). México D.F.: Instituto de Geografia, Universidad Nacional Autonoma de México, 1988.

IAPAR - INSTITUTO AGRONOMICO DO ESTADO DO PARANA. Cartas climáticas do Estado do Paraná 1994.Londrina: IAPAR, 1994.n. 1. Escala 1:1.000.000.

ITCG - INSTITUTO DE TERRAS, CARTOGRAFIA E GEOLOGIA (Paraná). Fotografias aéreas de 1980. Curitiba: ITCG, 1980. Escala: 1:25.000.

ITCG - INSTITUTO DE TERRAS, CARTOGRAFIA E GEOLOGIA (Paraná). Mapa Geológico do Estado do Paraná. Curitiba: ITCG, 2018.n. 1. Escala 1:650.000.

JUSTUS, Jarbas de Oliveira. Subsídios para interpretação morfogenética através da utilização de imagens radar. 1985. Dissertação (Mestrado) - Universidade Federal da Bahia, Salvador, 1985.

MAACK, Reinhard. Geografia Física do Estado do Paraná. Ponta Grossa: UEPG, 2012.

MACHADO, Fabio Braz; NARDY, Antonio José Ranalli; MELO, Rodrigo Prudente de; OLIVEIRA, Marcos Aurélio Farias de; SQUISATO, Eloiza. As rochas intrusivas da 
formação Serra Geral na porção leste da Bacia do Paraná no Estado de São Paulo: Aspectos petrográficos e geoquímicos-resultados preliminares. Geociências, Rio Claro, v. 24, n. 1, p. 5-17, 2005.

MAGALHÃES, Vanderlei Leopold. Gênese e evolução de sistemas pedológicos em unidades de paisagem do município de Marechal Cândido Rondon-PR. 2013. Dissertação (Mestrado em Geociências) - Universidade Estadual de Maringá, Maringá, 2013.

MINISTÉRIO DO EXÉRCITO. Folha Guaira SG-X-B-III/4. Folha Guaira-E SG-X-B-III-2. Folha Mercedes SG-X-B-III/4. Rio de Janeiro: Diretoria de serviço geográfico do exército, 1996. n. 1. Escala: 1:50.000.

MINEROPAR: MINERAIS DO PARANA. Atlas geológico do Estado do Paraná. Curitiba: MINEROPAR, 2001. n. 1. Escala: 1: 250.000.

MINEROPAR: MINERAIS DO PARANA. Folha Guairá. Curitiba: MINEROPAR, 2005.n. 1. Escala: 1:250.000.

MINEROPAR: MINERAIS DO PARANA. Atlas Geomorfológico do Estado do Paraná. Curitiba: MINEROPAR, 2006. n. 2. Escala: 1: 250.000.

MOURA, Thaiane Campos; MARQUES NETO, Roberto. Anomalias e lineamentos de drenagem na interpretação da dinâmica morfotectônica na bacia do alto rio Grande, Mantiqueira meridional. In: XI - ENCONTRO NACIONAL DA ANPEGE, 11., 2015, Presidente Prudente. Anais [...]. Presidente Prudente: UFGD, 2015. p. 6506-6517.

NAKASHIMA, Paulo. Sistema pedológico da região noroeste do estado do Paraná: distribuição e subsídios para o controle de erosão. 1999. Tese (Doutorado) - Universidade de São Paulo, São Paulo, 1999.

PASCHOAL, Leticia Giuliana; CONCEIÇÃO, Fabiano Tomazini da; CUNHA, Cenira Maria Lupinacci. Utilização do ArcGis 9.3 na elaboração de simbologias para mapeamentos geomorfológicos: Uma aplicação na área do Complexo Argileiro de Santa Gertrudes/SP. In: SIMPÓSIO NACIONAL DE GEOMORFOLOGIA, 8., 2010, Recife. Anais [...]. Recife: UFPE, 2010. p. 1-14.

PINTON, Leandro de Godói; CUNHA, Cenira Maria Lupinacci. O Uso de Geoindicadores em Paisagem Rural: Subsídios à Análise das Mudanças Morfológicas Antropogênicas da Bacia do Córrego Do Cavalheiro - Analândia (SP). Revista do Departamento de Geografia USP, v.29, p. 1-19, 2015

$\mathrm{ROCHA}$, Anderson Sandro da. As vertentes características e os sistemas pedológicos como instrumentos de analise para a identificação das fragilidades e potencialidades ambientais na Bacia Hidrográfica do Paraná 3. 2016. Tese (Doutorado em Geografia) Universidade Estadual de Maringá, Maringá, 2016.

SANCHES, Rafael Martins. Sistemas de transformação e suas relações com a erosão hídrica em solos de textura média em Terra Rocha - PR. 2018. Dissertação (Mestrado em Geografia) - Universidade Estadual do Oeste do Paraná, Marechal Candido Rondon, 2018.

STEFANUTO, Estêvão Botura; LUPINACCI, Cenira Maria. Avaliação das características ambientais de ocorrências das feições erosivas lineares nos limites depressão-cuesta Analândia (SP). Caminhos de Geografia, Uberlândia, v. 20, n. 70, p. 367-384, 2019. 
SOARES, Paulo Cesar; FIORI, Alberto Pio. Lógica e sistemática na análise e interpretação de fotografias aéreas em Geologia. Notícia Geomorfológica, Campinas, v. 16, n. 32, p. 71 104, 1976.

SOUZA, Tissiana de Almeida; OLIVEIRA, Regina Célia de. Avaliação da potencialidade de imagens tridimensionais em meio digital para o mapeamento geomorfológico. Revista GeoNorte, Manaus, v.2, n.4, p. 1348 - 1355, 2012.

TRICART, Jean. Principes et méthodes de lageomorphologie. Paris: Masson ET C éditeus, 1965.

VERSTAPPEN, Herman Theodoor; ZUIDAM, Robert van. ITC System of geomorphological survey. Enschede: International Institute for Aerial Surveyand Earth Sciences, 1975.

ZANATTA, Felipe Augusto Scudeller; LUPINACCI, Cenira Maria; BOIN, Marcos Noberto. O sistema de capacidade de uso da terra como instrumento para análise de área rural degradada. Caminhos de Geografia, Uberlândia, v. 20, n. 72, p. 55-77, 2019.

Recebido: março de 2021. Aceito: setembro de 2021. 